\title{
ANALISIS PRODUKSI PERKEBUNAN KARET DI KABUPATEN MUARO JAMBI
}

\author{
Prima Audia Daniel ${ }^{1}$
}

\begin{abstract}
In the long journey perekononomian people in Jambi province is inseparable from the role of the agricultural sector especially at sub-sector plantations. Until this time the sub plantation sector remains a mainstay in the economy of communities in the province with plant oil palm and rubber Prima Donna. However, in this research we restrict research on commodity production of rubber with the location of the research in the District of Muara Jambi. The main objective of this research was to look at the condition of the rubber commodity in the Regency and the scale of production that occurred in those commodities, with the subject areas of the rubber plantation commodities in the Muaro Jambi Regency. The results showed that the existence of significant influence between the land area with the production of the rubber produced. While the scale of commodity production in the rubber plants look shows the condition of increasing (increasing return to scale), it means an increase in output with greater proportions than in proportion to the addition of the input.
\end{abstract}

Keyword: production scale, increasing return to scale, rubber plantations.

\section{PENDAHULUAN}

Sektor perkebunan merupakan sektor utama yang mempunyai berperan penting di Provinsi Jambi baik dalam hal meningkatkan pendapatan juga sebagai penyeimbang dalam pelestarian lingkungan hidup serta sebagai instrumen pemerataan pembangunan rakyat. Hingga saat ini, tanaman karet masih menjadi primadona sekaligus menjadi andalan pada sub sektor perkebunan di Provinsi Jambi. Mengingat komoditas karet masih sebagai lokomotif ekonomi rakyat ddi provinsi ini. Dalam kesempatan ini ruang lingkup penelitian ini dilakukan di Kabupaten Muara Jambi, dengan tujuan agar lebih fokus pada permasalahan dan kondisi perkebunan komoditas karet di Kabupaten tersebut.

\footnotetext{
${ }^{1}$ STIE Muhammadiyah Jambi
} 
Tabel 1 Luas tanaman, produksi dan jumlah tenaga kerja pada sub sektor perkebunan karet di kabupaten muaro jambi tahun 2011 - 2015

\begin{tabular}{|c|c|c|c|c|c|c|c|}
\hline \multirow[b]{2}{*}{ Tahun } & \multicolumn{4}{|c|}{ Luas Areal / Area (Ha) } & \multirow[b]{2}{*}{$\begin{array}{l}\text { Produksi } \\
\text { (Ton) }\end{array}$} & \multirow[b]{2}{*}{$\begin{array}{l}\text { Prod. } \\
(\mathrm{Kg} / \mathrm{Ha})\end{array}$} & \multirow[b]{2}{*}{$\begin{array}{l}\text { Tenaga } \\
\text { Kerja }\end{array}$} \\
\hline & TBM & $\mathrm{TM}$ & $\begin{array}{l}\text { TTM/ } \\
\text { TR }\end{array}$ & Jumlah & & & \\
\hline 2011 & 15.404 & 34.475 & 8.106 & 57.985 & 29.690 & 861 & 14.951 \\
\hline 2012 & 15.878 & 33.841 & 8.525 & 58.244 & 29.464 & 871 & 15.118 \\
\hline 2013 & 16.374 & 31.329 & 8.164 & 55.867 & 31.603 & 1.009 & 15.190 \\
\hline 2014 & 17.101 & 33.369 & 7.954 & 58.424 & 32.506 & 974 & 15.190 \\
\hline 2015 & 17.667 & 33.405 & 7.382 & 58.458 & 32.345 & 968 & 15.220 \\
\hline
\end{tabular}

Sumber: Badan Pusat Statstik Provinsi Jambi

Dari tabel diatas menunjukkan bahwa Luas lahan, hasil produksi mengalami peningkatan berdasarkan jumlahnya. Artinya dengan melihat tren peningkatan yang terjadi tentu dalam beberapa tahun mendatang komoditas perkebunan ini akan semakin luas dan mampu menyediakan lapangan pekerjaan yang semakin meningkat. Dengan meningkatnya penyerapan tenaga kerja tersebut secara tidak langsung dapat mempercepat pembangunan yang dicita citakan.

Atas dasar hal tersebut penulis merasa sangat perlu dilakukan penelitian terkait dengan (1) Faktorfaktor apa saja yang mempengaruhi fungsi produksi karet; (2) Berapa elastisitas input terhadap output yang terjadi; dan (3) Bagaimana kondisi return to scale nya.

\section{KAJIAN PUSTAKA \\ Tanaman Karet}

Karet (Hevea brasiliensis) adalah tanaman perkebunan/industri tahunan berupa pohon batang lurus yang pertama kali ditemukan di Brazil dan mulai dibudidayakan pada tahun 1601 . Di Indonesia, Malaysia dan Singapura tanaman karet dicoba dibudidayakan pada tahun 1876 oleh Hendri A. Wickham. Tanaman karet di Indonesia pertama ditanamn di Kebun Raya Bogor. Karet cukup baik dikembangkan di daerah lahan kering beriklim basah. Tanaman karet memiliki beberapa keunggulan dibandingkan dengan komoditas lainnya, yaitu:

1. Dapat tumbuh pada berbagai kondisi dan jenis lahan, serta masih mampu dipanen hasilnya meskipun pada tanah yang tidak subur.

2. Mampu membentuk ekologi hutan, yang pada umumnya terdapat pada daerah lahan kering beriklim basah, sehingga keret cukup baik untuk menanggulangi lahan kritis.

3. Dapat memberikan pendapatan harian bagi petani yang membudidayakannya.

4. Memiliki prospek harga yang cukup baik.

\section{Teori Produksi}

Produksi dapat dinyatakan sebagai perangkat prosedur dan kegiatan yang terjadi penciptaan komoditas berupa kegiatan usahatani maupun usaha lainnya. Sebelum di lakukan proses produksi di lahan, terlebih dahulu di lakukan proses pengadaan saprodi (sarana produksi) pertanian berupa industri agro-kimia (pupuk dan pestisida), industri agrootomotif (mesin dan peralatan pertanian), dan industri pembenihan dan pembibitan. Untuk proses produksi di lahan, dapat digunakan faktor-faktor produksi seperti lahan, tenaga kerja, modal, pupuk, pestisida, teknologi, serta manajemen. Jadi, produksi komoditas pertanian merupakan hasil proses dari lahan pertanian dalam arti luas berupa komododitas pertanian (pangan, hortikultura, perkebunan, 
perikanan, peternakan, dan kehutanan) dengan berbagai pengaruh faktor-faktor produksi.

\section{Produktivitas}

Produktivitas

merupakan perbandingan antara hasil yang dicapai (keluaran) dengan keseluruhan sumber daya (masukan) yang dipergunakan per satuan waktu, definisi kerja ini mengandung cara atau metode pengukuran, walaupun secara teori dapat dilakukan secara tetapi secara praktek sukar dilaksanakan, terutama karena sumber daya masukan yang dipergunakan umumnya terdiri dari banyak macam dan di proporsi yang berbeda. Faktor-faktor yang mempengaruhi produktivitas : Pendidikan, Keterampilan, Sikap dan Etika kerja, Tingkat penghasilan, Jaminan sosial, Tingkat sosial dan Iklim Kerja, Motivasi, Gizi dan Kesehatan, Hubungan Individu, Teknologi dan Produksi.

\section{Konsep Tenaga Kerja}

Sunardi (1992, dalam Zulkarnain, 2008) menyatakan syarat seorang calon tenaga kerja yang baik antara lain yaitu memiliki pengetahuan luas, keterampilan yang memadai, mampu berkomunikasi secara lisan maupun tertulis dengan baik, memiliki motivasi yang kuat, mau bekerja keras, serta mampu bekerja secara cermat dan tepat. Tenaga kerja Indonesia perlu dibenahi karena ada lima sikap mental yang tidak mendukung peningkatan produktivitas yaitu : kurang disiplin, kurang kreatif, kurang inovatif, kurang motivasi, kurang dinamis dalam melaksanakan pekerjaan (Sunardi 1992, dalam Zulkarnain, 2008 dalam penelitian Cita Suci, 2016)

\section{Fungsi Produksi Cobb-Douglas \\ $Y=\alpha X 1^{b 1}{ }_{j} X 2^{b 2}{ }_{y} \ldots . . X n^{b n} e^{u}$}

Dimana:

$\mathrm{Y}=$ Variabel yang dijelaskan

$\mathrm{X}=$ Variabel yang menjelaskan

$\mathrm{a}, \mathrm{b}=$ Besaran yang akan digunakan

$\mathrm{e}=$ kesalahan (distrubance term)

Persamaan diatas sering disebut fungsi produksi Cobb-Douglas (Cobb Douglas production function). Fungsi Cobb-Douglas diperkenalkan oleh Charles W. Cobb dan Paul H. Douglass pada tahun 1920. Untuk memudahkan pendugaan terhadap persamaan di atas maka persamaan tersebut diperluas secara umum dan diubah menjadi bentuk linier dengan cara melogaritmakan persamaan tersebut. (Soekartawi, 2003) yaitu:

\section{$\log Y=\log a+b 1 \log X 1+b 2 \log X 2+b 3 \operatorname{LogX} 3+b 4 \log X 4+e$}

Karena penyelesaian fungsi Cobb-Douglas selalu dilogaritmakan dan diubah bentuknya menjadi linier, maka persyaratan dalam menggunakan fungsi tersebut antara lain (Soekartawi, 2003) :

1. Tidak ada pengamatan yang bernilai nol. Sebab logaritma dari nol adalah suatu bilangan yang besarnya tidak diketahui (infinite).

2. Dalam fungsi produksi perlu diasumsikan bahwa tidak ada perbedaan tingkat teknologi pada setiap pengamatan.
3. Tiap variabel $\mathrm{X}$ dalam pasar perfect competition. Perbedaan lokasi (pada fungsi produksi) seperti iklim adalah sudah tercakup pada faktor kesalahan (e).

Hasil pendugaan pada fungsi Cobb-Douglas akan menghasilkan koefisien regresi (Soekartawi, 2003). Dengan demikian, kemungkinan ada 3 alternatif, yaitu (Soekartawi, 2003):

1. Decreasing returns to scale, bila $(\mathrm{b} 1+\mathrm{b} 2)<1$. Kondisi ini terjadi bila tambahan output yang dihasilkan lebih kecil dibandingkan 
tambahan input-nya. (D\% output < D\% input).

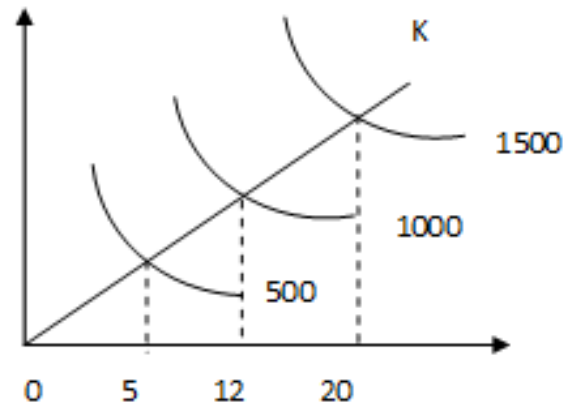

Keterangan gambar:

Penambahan presentase output lebih kecil dari penambahan input. Dari titik A ke titik B, kenaikan output naik $100 \%$, namun kenaikan penggunaan input lebih dari $100 \%$

2. Constant returns to scale, bila (b1 + b2) $=1$. Kondisi ini terjadi bila tambahan output yang dihasilkan sama dengan tambahan input-nya. (D\% output $=\mathrm{D} \%$ input $)$.

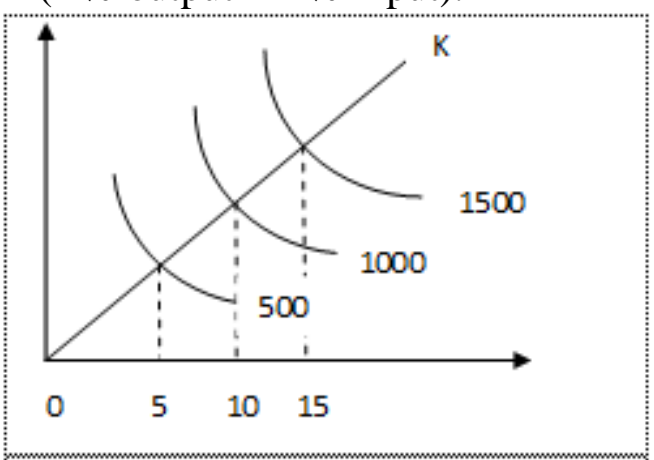

Keterangan gambar:

Perubahan output seiring dengan perubahan input. Pada saat input $\mathrm{L}$ yang digunakan 5 unit, output yang dihasilkan sebanyak 500 unit. Dengan bertambahnya penggunaan input L menjadi 10 unit (naik 100\%) maka output-nya pun naik dengan presentase yang sama.

3. Increasing returns to scale, bila (b1 + b2) > 1. Kondisi ini terjadi bila tambahan output yang dihasilkan lebih besar dibandingkan tambahan input-nya. (D\% output > D\% input)

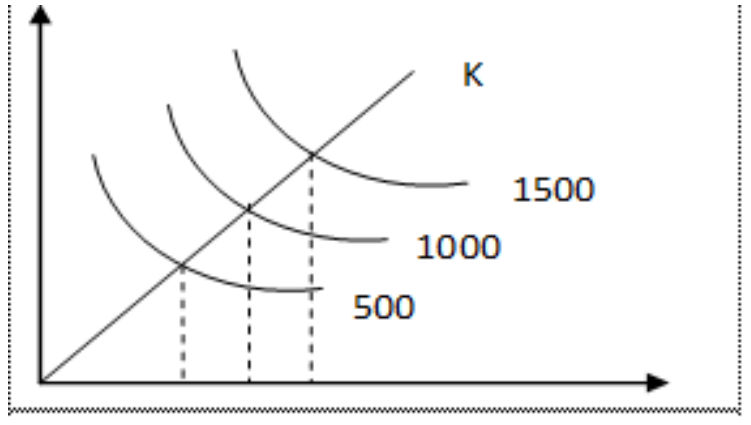

Keterangan gambar:

Perubahan presentase output lebih besar dari presentase kenaikan input. Pada saat output yang dihasilkan bertambah menjadi 1.000 unit (naik $100 \%$ dari mula-mula), penambahan presentase input kurang dari $100 \%$.

Fungsi Cobb-Douglas dapat dengan mudah dikembangkan dengan menggunakan lebih dari dua input (misal modal, tenaga kerja, dan sumber daya alam atau modal, tenaga kerja produksi, dan tenaga kerja non produksi).

\section{METODE PENELITIAN \\ Jenis Data dan Sumber Data}

Jenis data yang digunakan dalam penelitian ini adalah Data Sekunder. Data sekunder yang dipakai adalah data time series (runtut waktu) dari tahun 2001-2015. Sumber data dari BPS Muaro Jambi.

\section{Alat analisis}

Alat analisis yang digunakan dengan menggunakan model regresi linier berganda dengan pendekatan model Cobb Douglas. Yang selanjutnya dilakukan uji normalitas, Uji Multikolinieritas dan Uji Heteroskedastisitas

\section{HASIL PENELITIAN}

Hasil penelitian menunjukkan bahwa elastisitas dari masing-masing variabel independen adalah sebagai berikut. Elastisitas luas lahan sebesar 3.503274, elastisitas tenaga kerja sebesar -0.502716, elastisitas jumlah pohon sebesar -0.667313 dan elastisitas jumlah pupuk sebesar 0.213250 . 
Sedangkan besarnya return to scale dapat dihitung dengan menjumlahkan koefisien pangkat masing-masing variabel independen $(3.503274-0.502716-0.667313+$ $0.213250=2.546495)$ yang menunjukkan bahwa Perkebunan Karet di Kabupaten Muaro Jambi berada pada kondisi increasing return to scale.

\section{Uji Statistik $t$}

\section{Pengaruh Variabel Luas Lahan}

Hasil pengujian variabel luas lahan (dalam transformasi Log) menunjukkan bahwa variabel tersebut mempunyai nilai uji t sebesar 2.395692 dengan probabilitas sebesar 0,0376. Nilai t-tabel dalam persamaan ini adalah 2,228 (df $=10 ; 15-5)$. Dimana nilai t-hitung lebih dari nilai t-tabel dan nilai signifikansi t tersebut lebih besar dari taraf nyata $(0,05)$, maka hal ini berarti bahwa log luas lahan memiliki pengaruh yang signifikan terhadap produksi karet.

\section{Pengaruh Variabel Tenaga Kerja}

Hasil pengujian variabel luas lahan (dalam transformasi Log) menunjukkan bahwa variabel tersebut mempunyai nilai uji $t$ sebesar 0,352248 dengan probabilitas sebesar 0,7320 . Nilai t-tabel dalam persamaan ini adalah 2,228 ( $\mathrm{df}=10 ; 15-5$ ). Dimana nilai t-hitung kurang dari nilai t-tabel dan nilai signifikansi $t$ tersebut lebih kecil dari taraf nyata $(0,05)$, maka hal ini berarti bahwa log tenaga kerja tidak memiliki pengaruh yang signifikan terhadap produksi karet.

\section{Pengaruh Variabel Jumlah Pohon}

Hasil pengujian variabel luas lahan (dalam transformasi Log) menunjukkan bahwa variabel tersebut mempunyai nilai uji $t$ sebesar 0,949433 dengan probabilitas sebesar 0,3646 . Nilai t-tabel dalam persamaan ini adalah 2,228 (df $=10 ; 15-5$ ). Dimana nilai t-hitung kurang dari nilai $\mathrm{t}$-tabel dan nilai signifikansi $\mathrm{t}$ tersebut lebih kecil dari taraf nyata $(0,05)$, maka hal ini berarti bahwa log jumlah pohon tidak memiliki pengaruh yang signifikan terhadap produksi karet.

\section{Pengaruh Variabel Pupuk}

Hasil pengujian variabel luas lahan (dalam transformasi Log) menunjukkan bahwa variabel tersebut mempunyai nilai uji t sebesar 1,402531 dengan probabilitas sebesar 0,1910. Nilai t-tabel dalam persamaan ini adalah 2,228 (df $=10 ; 15-5)$. Dimana nilai t-hitung kurang dari nilai t-tabel dan nilai signifikansi t tersebut lebih besar dari taraf nyata $(0,05)$, maka hal ini berarti bahwa log pupuk tidak memiliki pengaruh yang signifikan terhadap produksi karet.

\section{Uji Statistik F}

Analisis regresi dilakukan dengan menggunakan Eviews. Berdasarkan tabel 5.6 nilai F-hitung sebesar 8.476967 dan nilai f-tabel pada tingkat signifikansi 0,05 di dapat 3,48. Hal ini menunjukkan bahwa nilai F-hitung $>\mathrm{f}$ tabel atau 8,47 > 3,48 maka Ho ditolak dan Ha diterima, artinya secara simultan variabel independent yaitu luas lahan, tenaga kerja, jumlah pohon dan pupuk secara bersama-sama berpengaruh signifikan terhadap produksi di Kabupaten Muaro Jambi.

\section{Koefisien Determinasi $\left(R^{2}\right)$}

Pada perhitungan statistik diperoleh besarnya koefisien determinasi $\left(\mathrm{R}^{2}\right)$ sebesar 0.772250 . Hal ini menunjukkan bahwa Produksi Karet di Kabupaten Muaro Jambi mampu dijelaskan oleh Luas Lahan, Tenaga Kerja, Jumlah Pohon dan Pupuk hanya sebesar $77 \%$, sedangkan sisanya sebesar $23 \%$ dipengaruhi oleh faktor lain yang tidak termasuk dalam penelitian ini.

\section{Uji Normalitas}




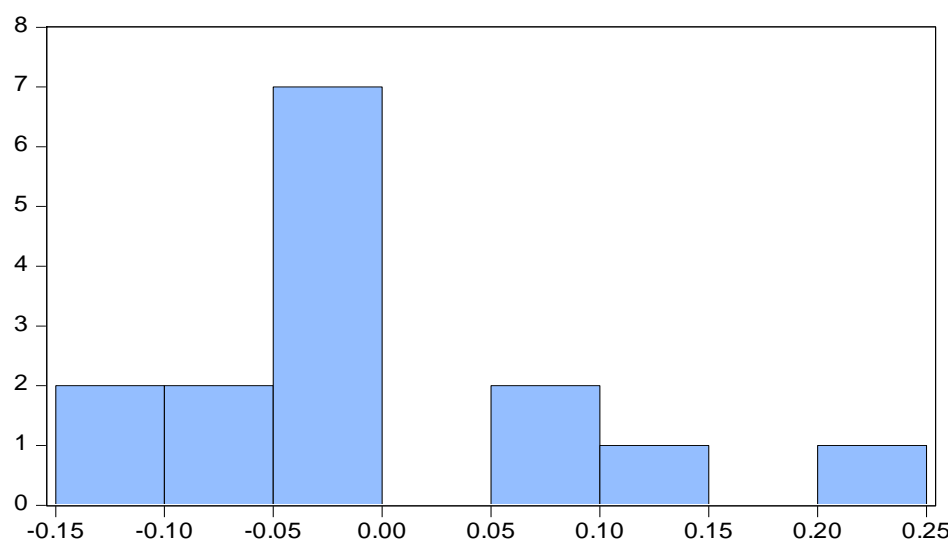

Uji Multikolinearitas

Tabel 2 Hasil Uji Multikolinearitas

Variance Inflation Factors

Date: 10/09/17 Time: 12:35

Sample: 20012015

Included observations: 15

\begin{tabular}{llll}
\hline \hline & \multicolumn{2}{l}{ Coefficient } & \multicolumn{2}{l}{ Uncentered Centered } \\
Variable & Variance & VIF & VIF \\
\hline \hline C & 233.2840 & 282480.1 & NA \\
LN_LUAS_LAHA & & & \\
N & 2.138387 & 312176.3 & 9.685543 \\
LN_TENAGA_KE & & & \\
RJA & 2.036802 & 228670.3 & 1.203387 \\
LN_JUMLAH_POH & & & \\
ON & 0.494003 & 160940.9 & 9.273021 \\
LN_PUPUK & 0.023118 & 6977.461 & 1.351455 \\
\hline \hline
\end{tabular}

Sumber: data diolah dengan eviews 7,0

Dari tabel dapat dilihat bahwa

tidak terdapat variabel yang memiliki

nilai lebih dari 10, sehingga dapat

multikolinearitas diantara variabel disimpulkan diduga tidak terjadi bebas dalam model regresi.

Uji Heteroskedastisitas

Heteroskedasticity Test: White

\begin{tabular}{lrll}
\hline \hline F-statistic & 0.562279 & Prob. F(4,10) & 0.6956 \\
Obs*R-squared & 2.754218 & Prob. Chi-Square(4) & 0.5998 \\
Scaled explained SS & 1.696127 & Prob. Chi-Square(4) & 0.7914
\end{tabular}

Sumber: hasil output regresi eviews 7

Dari Tabel 3 menunjukkan bahwa uji white menghasilkan kesimpulan tidak ada masalah heteroskedastisitas, hal ini dibuktikan dengan nilai Obs*R-squared 2.754218 dengan prob 0.5998 , maka 0.5998 > 0,05 .

\section{Uji Autokorelasi}

Pada hasil uji LM ini diketahui bahwa nilai Probabilitas Chi-Square sebesar $0,5070>\alpha$. Dimana $\alpha=5 \%$ atau 0,05. Berdasarkan tabel 5.5 nilai Durbin - Waston sebesar 1,605. Syarat tidak terjadi autokorelasi jika du $<\mathrm{dw}$ 
< 4-du. Dengan data 15 sampel dan 5 variabel, diketahui nilai du sebesar 0,56 dan 4-du sebesar 1,78 sehingga dapat diambil kesimpulan $0,56<1,605<$ 1,78. Sehingga dapat kesimpulan tidak terjadi autokorelasi.

\section{SIMPULAN}

bahwa :

Hasil penelitian menunjukkan

1. Variabel luas lahan (X1) positif dan signifikan terhadap hasil produksi (Y) sementara variabel X2 (tenaga kerja), X3 (jumlah pohon), X4 (pupuk) tidak berpengaruh positif dan signifikan terhadap jumlah produksi yang dihasilkan.

2. Besarnya elastisitas X1 (luas lahan) terhadap produksi sebesar 3,503274 menunjukkan besaran luas lahan bersifat elastis karena $\mathrm{E}>1$, Besaran elastisitas tenaga kerja sebesar -0,502716, elastisitas jumlah pohon sebesar $-0,667313$ dan elastisitas pupuk sebesar 0,213250. Hasil tersebut menunjukkan bahwa elastisitas pada setiap variabel input lebih kecil daripada satu. Sehingga tenaga kerja, jumlah pohon dan pupuk bersifat inelastis.

3. Hasil analisis menunjukkan bahwa parameter $\mathrm{b}+\mathrm{c}+\mathrm{d}+\mathrm{e}=2,546495$ lebih besar dari 1. Artinya skala produksi yang terjadi pada perkebunan karet di Kabupaten Muaro Jambi adalah increasing return to scale, artinya peningkatan output yang terjadi proporsinya lebih besar daripada proporsi penambahan inputnya.

\section{Saran}

1. Pemerintah dan masyarakat perlu meningkatkan luas lahan karet dan peremajaan tanaman karet, disamping penggunaan pupuk, kondisi lahan (unsur hara), dan jarak tanam yang tepat agar mampu meningkatkan produktivitas produksi karet yang lebih baik.
2. Pemerintah diharapkan dapat meningkatkan peran dari para penyuluh pertanian sehingga dapat memberikan informasi (alih teknologi) terhadap petani terkait cara penggunaan input produksi secara efisien sehingga mampu meningkatkan produksi

\section{DAFTAR PUSTAKA}

Agustina, Shinta., Ir., M.P. 2011. Ilmu Usaha Tani. Universitas Brawijaya Press (UB Press). Cetakan Pertama. Malang, 65145 Indonesia.

Badan Pusat Statistik, 2015. Data Produk Domestik Regional Bruto Kabupaten Muaro Jambi 2011 2015, Jambi.

BPS. (2016) Muaro Jambi Dalam Angka : Badan Pusat Statistik (BPS) Kabupaten

Muaro Jambi.

BPS. Statistik Perkebunan Provinsi Jambi, Tahun 2011-2015. Pemerintah Provinsi Jambi. Dinas Perkebunan

Cita, Suci. 2016. Pengaruh Modal, Tenaga Kerja, Dan Biaya Standar Terhadap Peningkatan Produksi Pada Industri Kecil. Jurusan Ekonomi Syariah. Sekolah Tinggi Agama Islam Darul Arqam (Staida) Muhammadiyah Garut. http://citasuci448.blogspot.co.id/ 2016/07/pengaruh-modaltenaga- kerja-dan-biaya.html

Disbun, Provinsi Jambi, Tahun 2001 2015. Data Perkebunan Karet di Kabupaten Muaro Jambi, Dinas Perkebunan Provinsi Jambi.

Hastuti, Diah Dwi Retno. 2007. Pengantar Teori dan Kasus: Ekonomika Pertanian. Jakarta : Penebar Swadaya.

Hermanto, Bambang. 2013. Analisis Fungsi Produksi Usahatani Padi Sawah dan Pengaruhnya Terhadap Produksi Domestik Regional Bruto (PDRB) Untuk 
Pengembangan Wilayah di Kabupaten Deli Serdang. Universitas Muslim Nusantara Al Washliyah, Medan.

Hortus Redaksi, Majalah. 2015. Potensi Daerah Sawit dan Karet Jadi Andalan Provinsi Jambi. www.majalahhortus.com/potensidaerah/item/65-sawit- dan-karetjadi-andalan-provinsi-jambi.html

Hutagaol, Satya Novecty 2015. Analisis Usahatani Karet (Hevea Brasiliensis) Di Provinsi Jambi. Sekolah Pascasarjana. Institut Pertanian Bogor, IPB.

Joesron, Tati Suhartati. 2012. Teori Ekonomi Mikro Dilengkapi Beberapa Bentuk Fungsi Produksi. Penerbit : Grahailmu Yogyakarta

Jono, 2016. Analisis Produktivitas Pabrik Spiritus Menggunakan Fungsi Cobb- Douglas. Studi Kasus di PT. XYZ. Yogyakarta. Jurusan Teknik Industri, Universitas Widya Mataram, Yogyakarta.

Jumin, Hasan Basri,. Ir., 1998. DasarDasar Agronomi. Penerbit Rajawali. Cetakan Ke: Edisi 1/2

Jumin, Hasan Basri., Prof., Dr., M.Sc., 2008. Dasar-Dasar Agronomi. Edisi Revisi. PT. Grafindo Persada, Jakarta.

Junaidi, Dr., SE., M.Si. 2015. Buku Ajar Ekonometrika 1. Fakultas Ekonomi dan Bisnis, Universitas Jambi. FEB-UNJA

Listianawati, Nita Nur. 2014. Analisis Faktor-Faktor Yang Mempengaruhi Produksi Bawang Merah di Desa Kupu Kecamatan Wanasari Kabupaten Brebes. Jurusan Agribisnis, Fakultas Sains Dan Teknologi, UIN Syarif Hidayatullah, Jakarta.

Mayyendra, Repni. 2010. Peranan perkebunan karet terhadap perekonomian kabupaten kuantan singingi. Provinsi Riau.
Noer Ahmad, Sugito., Drs., S.U., 2011. Statistika Lanjutan. Edisi Pertama. Fakultas Ekonomi. Universitas Jendral Sudirman, Puwokerto.

Nurfathiyah, Pera dkk, 2007. Faktorfaktor yang melatarkebelakangi keputusan

petani dalam mengusahakan komoditi karet di desa pasar terusan kecamatan muara bulian, Kabupaten Batanghari. Fakultas Pertanian, UNJA (penyuluhan dan komunikasi pertanian)

Pujiati, Tatik. 2013. Analisis Pengaruh Beberapa Faktor Terhadap Produksi Karet di PTPN IX (Persero) Kebun Batujumus Kabupaten Karanganyar. Universitas Sebelas Maret.

Rosari, Vinta, 2013. Analisis Fungsi Cobb-Douglas Pada Pabrik Gula. Studi Kasus pada PT. Madubaru Di Tirtonimolo, Kasihan, Bantul, Yogyakarta. Fakultas Ekonomi, Universitas Sanata Dharma, Yogyakarta.

Soekartawi, 2002 Fungsi Produksi Cobb-Douglas, Faktor-faktor yang mempengaruhi Produksi. Ekonomi Pertanian.

Soekartawi. 2002. Analisis Usahatani. Penerbit Universitas Indonesia (UI-Press), Jakarta.

Sukirno, Sadono. 2003. Pengantar Teori Mikro Ekonomi. Jakarta: PT Raja Grafindo Persada.

Tri Bowo, 2010. Analisis faktor-faktor yang mempengaruhi produksi belimbing. Studi Kasus Desa Betokan, Kabupaten Demak. FE, Universitas Diponegoro Semarang.

Wikipedia, ID. 2017. Kabupaten Muaro Jambi,. Ensiklopedia. www.muarojambikab.go.id

Wikipedia, ID. 2017. Pohon atau bibit. Pengertian dan fungsi. Ensiklopedia. 
Zulfahmi Arif, Muhammad Guruh.

2012. Tri tunggal Usahatani.

http://kickfahmi.blogspot.co.id/2

012/09/tri-tunggal-usaha-

tani.html 